研 究 論 文

\title{
ワイヤーモーションに伴う超伝導コイル クエンチ現象の動力学的解析
}

\author{
西嶋 茂宏, 櫛田 達也*，岡田 東一 \\ 大阪大学産業科学研究所 茨木市美穂ヶ丘 8-1
}

（1997 年 2 月 20 日受理）

\begin{abstract}
Dynamic Simulation of Coil Quench Induced by Wire Motion
Shigehiro NishiJIma, Tatsuya KushidA* and Touichi OkadA

Institute of Scientific and Industrial Research, Osaka University, 8-1 Mihogaoka, Ibaraki 567
\end{abstract}

(Received February 20, 1997)

\begin{abstract}
Synopsis :
Wire motion in a superconducting coil has been simulated dynamically by means of solving the equation of motion of each winding with time in order to make quantitative analyses of the relationships between the winding conditions and the quench current of a superconducting coil, especially between winding tension and quench current. Using this method, each wire position, wire velocity and frictional heating and stress in the coil during excitation could be calculated dynamically. It was found that not only quench current but also the position where quench initiates changed with the winding tension and frictional coefficient. Wire motion after quench was also calculated. It was clarified that, due to the friction force, the wire did not return to its initial position resulting in misalignment of the wire. It was found that the method developed is useful for revealing the characteristics of a superconducting coil during operation. The method can be applied to the design of stable super conducting magnets.
\end{abstract}

Keywords : wire motion, winding tension, frictional coefficient, quench current, dynamic simulation

\section{1. 序論}

超伝導磁石においてワイヤーモーションにともなう クエンチ現象は, 重大な問題となることが知られてい

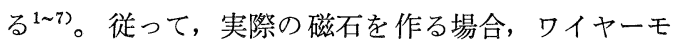
ーションを抑制できる磁石構成にすることが望ましい が, 実際的, 経験的要素が強く, 線材の性能を最大限 に生かした安定な磁石を作る方法論は確立されている とは言えない。これは擾乱の大きさとコイル構成につ いての関係を定量化できていないことが原因と考えら れる。例えば, ワイヤーモーションを抑え, 特性を向 上させるための線材と巻枠の摩擦係数に最適值がある

\footnotetext{
*現在, NTT 関西支社総務部勤務
}

のか，また，巻き張力についてはどうなのか，さまざ まな議論がなされてはいるものの, 定量的にそれらと ワイヤーモーション，さらにはクエンチ電流 $\left(I_{\mathrm{q}}\right)$ と の関連性について議論されている研究は少ない。 我々は, 磁石を作る構成材料の材料の物性と, クエ ンチ電流との相関性についての定量的な議論を行うた めに，新しいワイヤーモーションの解析法を考案した が8,9)，この計算手法を用いて 4 層 118 ターンのコイル について計算を行い, 静摩擦係数, 巻き張力と $I_{\mathrm{q}}$ と の相関関係について議論を行った。また，この計算手 法では通電前後及び通電中のコイル内の応力分布, 線 材の速度分布, 発熱分布, 線材の位置等を明らかにで きるので，トレーニング現象を定量的に解析できる可 能性があることも明らかになったので，その結果にっ 


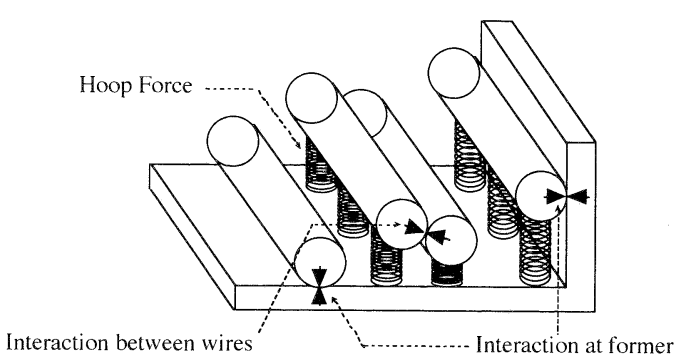

Fig. 1 Schematic illustration of analyzed system.

いて報告する。

\section{2. 計算方法}

開発した計算方法は，基本的にはコイル内の 1 本 1 本の線材の運動方程式を時間発展で解くことにより行 われる。コイル内の線材の運動方程式を立てるため に，Fig. 1 で示すようなコイルのモデル化を行った。 このモデルでは，コイルは円柱状の線材がそれぞれ相 互作用を及ぼし合いながら積み重なっていると考光 る。さらにモデル内にフープカを取り込むため, 線材 は巻枠胴部にバネで連結されていると模擬する。この ようにモデル化したコイル内では, 時間 $t$ での $i$ 番目 の線材の運動方程式は次の式で与えられる。

$$
\begin{aligned}
& v_{i}=\mathrm{d} r_{i} / \mathrm{d} t \\
& F_{i}=I \times B_{i}+f_{i}+T_{i} \\
& \mathrm{~d} v_{i} / \mathrm{d} t=\left(1 / m_{i}\right) \cdot F_{i}-\zeta v_{i}
\end{aligned}
$$

ここで, $r_{i}$ 及び $v_{i}$ は時刻 $t$ での $i$ 番目の線材の位 置と速度, $m_{i}$ は線材の質量, $F_{i}$ は線材に働く力の総

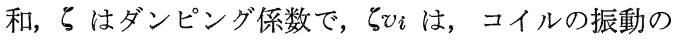
減衰項に相当する。また, $I$ は電流值, $B_{i}$ は $i$ 番目 の線材のある場所での磁界, $f_{i}$ は他の線材や巻枠より 働く力と摩擦力の和, $T_{i}$ はフープ力である。 $f_{i}$ に線 材の半径方向の弾性率や線材同士, 線材と巻枠間の摩 擦係数といった材料定数が関係することになる。 $B_{i}$ は ビオ・サバールの法則から求めた。 $I \times B_{i}$ は線材に作 用するローレンツカであり, 通電電流とその線材の位 置に打ける磁界とから計算された。フープ力は線材の 巻き張力により生ずる力であるが，平衡位置から線材 が動く場合にその 1 ターンの長さ変化に応じたフープ 力が生ずると考えている。つまり前述したように線材 はバネで巻枠胴部に連結されたと模擬しこのバネ定 数に線材長手方向の弾性率を当てはめた。線材間の相 互作用と線材と巻枠の相互作用はヘルッの式 ${ }^{10)} よ り$ 線 材の変形量とその反力の形で計算中に反映されてい
Table 1 Mechanical and thermal properties of the $\mathrm{NbTi}$ superconductor used in the calculation (at $4.2 \mathrm{~K}$ ).

$\begin{array}{ll}\mathrm{Cu} / \mathrm{NbTi} \text { ratio } & 1.0 \\ \text { Diameter } & 2.0 \mathrm{~mm} \\ \text { Young's modulus } & 110 \mathrm{GPa} \\ \text { Density } & 8.65 \times 103 \mathrm{~kg} / \mathrm{m}^{3} \\ \text { Specific heat } & 0.52 \mathrm{~J} / \mathrm{kg} \cdot \mathrm{K} \\ \text { Critical current } & 4,860 \mathrm{~A} \text { at } 0 \mathrm{~T} \\ & 2,255 \mathrm{~A} \text { at } 5 \mathrm{~T}\end{array}$

る。ただしここでは変形を生じるのは線材のみとし， 巻枠の変形は考慮に入れていない。即ち巻枠は剛体と して扱っている。このようなモデルで，本解析では密 巻きソレノイドコイルの模擬を行った。Table 1 に計 算に使用した線材の物性値を示した。

これらの式を使って, 個々の線材の位置, 速度及び 加速度が計算される。具体的には，これらの一階の連 立常微分方程式の初期值問題を解くことになる。初期 值としては，各線材の位置と速度を与える。ただし各 線材の初期速度は $0 \mathrm{~m} / \mathrm{s}$ とした（初期位置については 後述する)。この線材の初期位置から線材各々に働く 力が計算され, 力から加速度が, 加速度から速度が順 次計算される。そして求められた速度を使って 1 タイ ムステップ後の新たな線材の位置が決定される。以後 同じ手順を繰り返すことにより，時間発展で連立常微 分方程式が解けることになる。時間積分はオイラー法 を使用した。

ここでらの意味について考えておく。式からも分か るようにら琼は速度に比例した抵抗力で線材の動きの 減衰又は粘性抵抗を意味している。材料学的には材料 の内部摩擦等, 静的材料定数に現れてこない減衰項と 考えることができる。計算ではこの項の導入で, 結果 として系の安定化が図られることになる。またクエン チ後のコイル挙動を考える際, この項がないと長時間 振動現象が現れ (エネルギーが系に保存されるため), 線材のクエンチ後の静止位置を時間内に計算できな い。そこで大きな粘性保数を導入し，振動を強制的に 静止させるという意味もある。ここでは計算時間内に 減衰が終了するように減衰の時定数, $1 / \zeta$ を $25 \mu \mathrm{s}$ と した。

時間 $t$ における最内層の各線材の MQE (Minimum Quench Energy) を計算し（実際のコイルでは, 1 本 の線材を連続して巻き付けてあるのだが，ここでは 1 ターンずつ独立した輪を作っていると近似して計算を 行った), 巻枠に押しつけられる力と移動距離とから計 
算された摩擦熱との比較がなされた。摩擦熱が $\mathrm{MQE}$ を越えた時点で電流を止め, そのときの電流值を $I_{\mathrm{q}}$ と した。ここで, 巻枠と線材間の摩擦により発生した熱 のうち，1/2 が線材に蓄えられるとした。また,線材同 士の摩擦熱は, それぞれの線材に $1 / 2$ ずつ分配される ものと考えた。以上のような計算手法により，巻き張 力, 摩擦係数を変化させて計算を行った。なお, 当計算 では密巻きコイルを扱っているので断熱条件を考え, $\mathrm{MQE}$ は液体へリウム温度から分流開始温度までの 1 ターンのエンタルピーで定義している。摩擦発熱も 1 ターン全体が均等に摩擦を起こすと想定しているの で，比較する $\mathrm{MQE}$ としては，1 ターンごとの $\mathrm{MQE}$ を考えた。超伝導線材の比熱は, $\mathrm{NbTi}$ と銅の比熱の 温度依存性を考慮した近似式で求めた。Table 1 には MQE を求めるのに使用した材料定数も示してある。

励磁前の線材の配置の決定は（コイル巻線に相当す る), 以下の過程で行った。線材をまず 1 層だけ配 置 する。この配置は線材同士及び線材と巻枠が接するよ うに配置する。この時点ではまだ線材は変形していな い。その後巻き張力を加え, 線材の変形を考慮し一 定時間その状態で放置し平衡状態を達成する。この 際, 線材の位置は, 巻き張力と巻枠反力のつり合いか ら決定される。その後次の層の線材を俵積みに配置す る。 2 層目の配置を行うとき, 1 層目の線材は圧縮さ れることになるので, この 1 層目の反力も考慮して, 2 層目の配置が決定された。この過程を繰り返し 4 層 巻き付けた。これにより, 実際のコイルの巻線過程を 模擬したことになる。そして，安定になった時のその 線材の位置を励磁前の線材の平衡位置とした。そこか ら線材が半径方向に動いた場合, フープ力に変化が生 じるとした。タイムステップは $5 \times 10^{-7} \mathrm{~s}$ とし, 通電 電流は 1 ステップにつき $3 \mathrm{~A}$ ずつ， $0 \mathrm{~A}$ から臨界電流 值 $\left(I_{\mathrm{c}}\right)$ の $2,391 \mathrm{~A}$ まで一定の上昇率 $\left(6.0 \times 10^{6} \mathrm{~A} / \mathrm{s}\right)$ であげられている。各タイムステップでそれぞれの線 材について運動方程式が解かれている。計算に使用さ れたモデルコイルの仕様を Table 2 に示す。 4 層 118 ターンの密巻きコイルであり, 直径 $2 \mathrm{~mm}$, 銅比 1 の $\mathrm{NbTi}$ 超伝導線材が使用されている。

ここで本解析コードの現状での限界について述べて おく。本解析では初期值として線材の初期配列を与え るのみなので, 俵積みされている密巻きコイルにおけ るデータ入力の煩雑さはほとんどない。問題は計算時 間にあり，本解析で使用した 4 層 118 ターンの計算で 現在約 15 時間かかっている。この理由は, 各タイム
Table 2 Specifications of the analyzed superconducting coil.

$\begin{array}{ll}\text { Inner diameter } & 40 \mathrm{~mm} \\ \text { Outer diameter } & 54.4 \mathrm{~mm} \\ \text { Coil length } & 60 \mathrm{~mm} \\ \text { Number of turns } & 118 \\ \text { Number of layers } & 4 \\ \text { Critical current } & 2,391 \mathrm{~A} \\ \text { Magnetic field } & 4.28 \mathrm{~T}\end{array}$

ステップで磁場分布を計算し直していることによる。 これは, 線材の動きに伴い磁場分布が変化することを 想定していたためである。しかし，計算結果を見ると クエンチまでの線材の動きは数 $\mu \mathrm{m}$ 程度であるので, 磁場分布の変化を無視できることが明らかとなった。 それゆえ, 線枋が動いても磁場分布形状は変化しない として計算を行えば，ターン数を増加させても計算時 間の大幅な短縮が図られ，より実用的な計算コードに なると考えられる。また, 現状では解析できる体系は 断面が円形の線材でできたコイルに限られている。

\section{3. 計算結果及び考察}

\section{1 巻枠胴部の反力の変化}

Fig. 2 は励磁前の段階で, 各層を巻いた場合の巻枠 の反力の変化を示している。まず 1 層目の 30 本の線 材を配置し張力を加え平衡状態を達成する。平衡状態 達成のために 2,000 ステップの緩和を行った。これに より巻枠胴部の反力 (REACTY) は約 $10,000 \mathrm{~N}$ とな

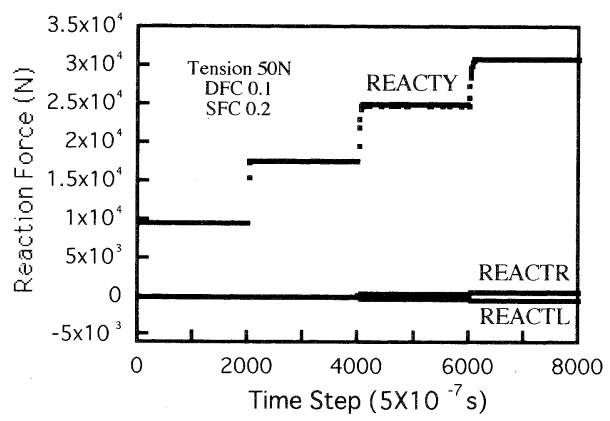

Fig. 2 Reaction forces from bobbin while winding a coil at a winding tension of $50 \mathrm{~N}$. REACTY, and REACTR and REACTL represent the reaction force from the bobbin barrel and flanges, respectively. Dynamic frictional coefficient (DFC) and static frictional coefficient (SFC) between wire and bobbin are set at 0.1 and 0.2 , respectively. 

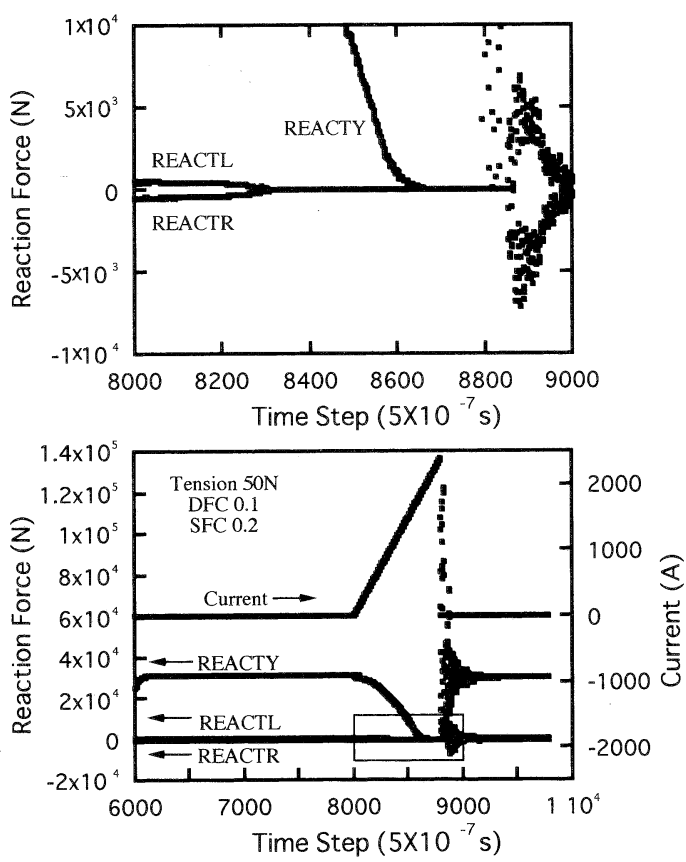

Fig. 3 Change in reaction forces from bobbin barrel (REACTY) and bobbin flanges (REACTR and REACTL) at a winding tension of $50 \mathrm{~N}$. The upper section is an enlargement of the rectangle area at the bottom. DFC: dynamic frictional coeffcient; SFC: static frictional coefficient.

り安定になる。2, 000 ステップで 2 層目を巻き, 2,000 ステップの間放置することにより巻枠胴部の反力は $18,000 \mathrm{~N}$ で安定になる。さらに 4 層まで線材を巻き 安定化させた時には, 反力は 8,000 ステップで約 $30,000 \mathrm{~N}$ となり安定になる。巻枠胴部反力の増加と 共につば部反力（左側つば部からの反力 : REACTL, 右側つば部からの反力 : REACTR) も増加していく。 巻層数を増やすにつれ, 反力の増加量は少なくなって おり，実際の現象を良く反映している。これは，下層 の線材の反力を考慮しているためで, 通常の計算の多 重円筒モデルに相当している。またこの反力の 30,000 $\mathrm{N}$ を巻枠の断面積 $7,536 \mathrm{~mm}^{2}$ で除せば巻枠の応力と なる。な㧍この計算では, 巻き張力 $50 \mathrm{~N}$, 静摩擦係数 0.2 , 動摩擦係数 0.1 として計算を行った。巻枠の変 形を考虑していないので, 少し高い応力値が現れてい ると考えられる。

次にこのコイルを $I_{\mathrm{q}}\left(I_{\mathrm{c}}=2,391 \mathrm{~A}, I_{\mathrm{q}}=2,355 \mathrm{~A}\right)$ ま で通電した時の応力を計算した。Fig. 3 がその結果で
あるが, 通電開始 $(8,000$ ステップ) 後, 胴部及びっ ば部からの反力は小さくなっていき， 8, 310 ステップ (930 A) でつば部からの反力 (REACTL, REACTR) が $0 \mathrm{~N}$ となる。次いで 8,667 ステップ $(2,001 \mathrm{~A})$ で 胴部からの反力 (REACTY) が $0 \mathrm{~N}$ となり, 巻枠か ら線材部が浮き上がる現象が起こっていることが分か る。このような巻枠から巻線部が浮き上がる現象は報

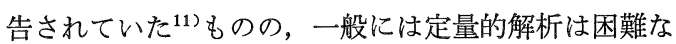
挙動である。しかし本解析はそれを可能にすると言え る。またクエンチ後電流を遮断すると（通電電流を $0 \mathrm{~A}$ にするという意味で,ここでは 8,785 ステップ目） 巻線はまず胴部にぶつかり, 若干遅れてつば部の反力 が現れ，その後振動が減衰する様子が見られる。

\section{2 コイルの安定性}

Fig. 4 は同形状の 4 層コイルで巻き張力を $50 \mathrm{~N}$ か ら $500 \mathrm{~N}$ まで変化させた場合の巻き張力の $I_{\mathrm{q}}$ に及ぼ す効果を示したものである。 $I_{\mathrm{q}}$ は $I_{\mathrm{c}}$ で規格化されてい る。巻枠と線材間の静摩擦係数は 0.2 と 0.6 の二つの 場合を計算しており，動摩擦係数は共に 0.1 で同じに している。摩擦係数 0.6 は液体へリウム温度での銅 ステンレスの平均的な最大摩擦係数であり, また 0.2 はこの最小值に近い值である。図より分かるように, 静摩擦係数が $0.2 ， 0.6$ の場合で共に張力の増加に 対 し， I はそれぞれ $200 \mathrm{~N}$ と $150 \mathrm{~N}$ 付近で, 最小值を 示すような変化を示している。このことは，コイル構 成材料の材料定数が安定性汇影響を及ぼすことを意味 しており, 安定なコイル製作には適切な材料選択や加 工が必要であることを示唆している。以下この現象の 原因について計算結果を基に考察する。

Fig. 5 (a) は静摩擦係数が 0.2 で巻き張力が $200 \mathrm{~N}$

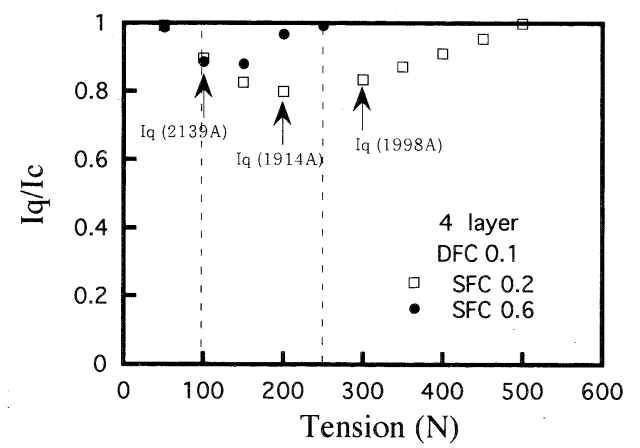

Fig. 4 Change of quench current as a function of winding tension at a static frictional coefficient (SFC) of 0.2 or 0.6 . Dynamic frictional coefficient (DFC) is set at 0.1 . 


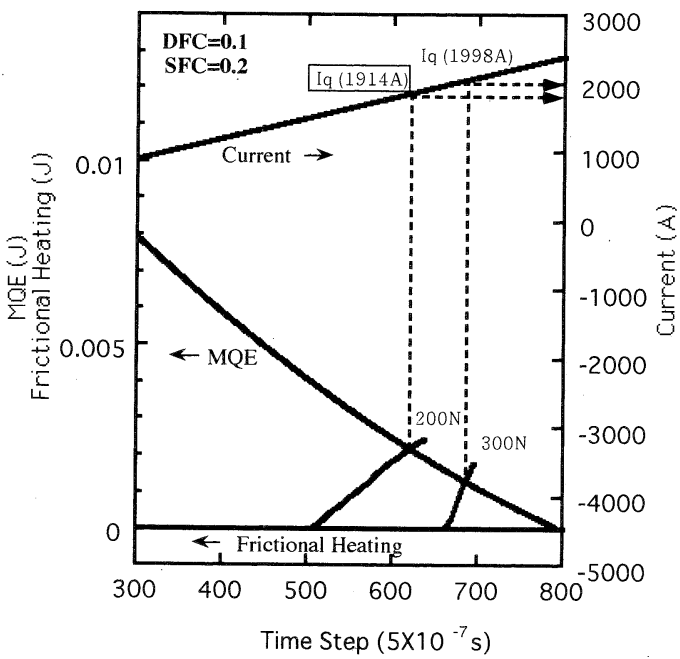

(a)

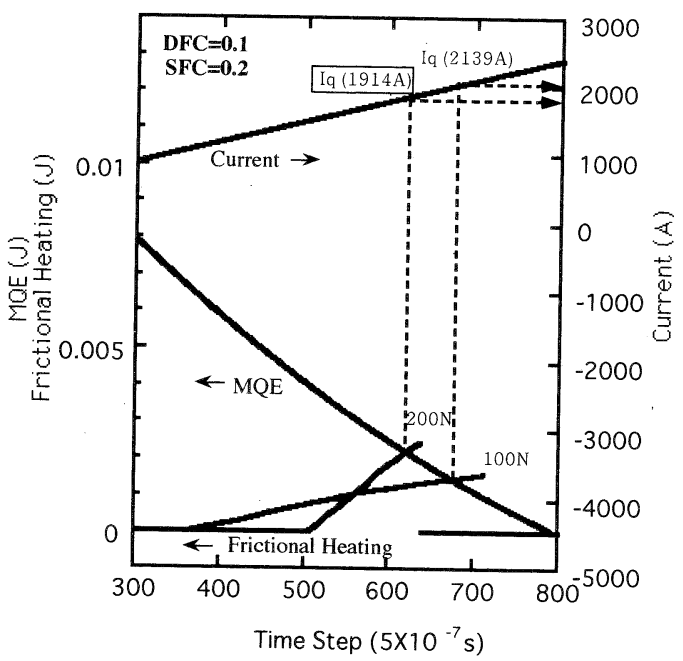

(b)

Fig. 5 Change of frictional heating and MQE with excitation. (a) At a winding tension of 200 or $300 \mathrm{~N}$; (b) At a winding tension of 100 or $200 \mathrm{~N}$. DFC: dynamic frictional coefficient; SFC: static frictional coefficient.

と $300 \mathrm{~N}$ の時の, 各ターンの中で最も小さい $\mathrm{MQE}$ と, 最も大きな摩擦発熱の変化を通電電流に対して示 したものである。なお, $200 \mathrm{~N}$ の巻き張力の時, この コイルは最小の $I_{\mathrm{q}}$ を示す（後で，発熱量の空間分布 を議論するが, 線材同士の発熱量は線材と巻枠間の発 熱量に比較して十分小さいので，クエンチに直接関係 するのは線材と巻枠間の発熱であることが導かれる)。 $M Q E$ は通電電流の増加と共に減少していく。摩擦発 熱は線材が巻枠に対して動き始めるのに伴い増加を始 め, 摩擦発熱が $\mathrm{MQE}$ を越えた際の電流值が $I_{\mathrm{q}}$ に相 当する。Fig. 5 (a) より巻き張力の大きな $300 \mathrm{~N}$ の方 が線材の動き始める電流值が大きくなりこれが原因で $I_{\mathrm{q}}$ が高くなっていることが分かる。

Fig. 5 (b) は静摩擦保数は同じく 0.2 で, 巻き張力が $100 \mathrm{~N}$ と $200 \mathrm{~N}$ で同様のプロットを行ったものであ る。動き始めの電流值は (a) と同様, 巻き張力の高い $200 \mathrm{~N}$ の方が高くなっている。即ち, 巻き張力 $100 \mathrm{~N}$ の方が線材が動き出す電流值は低いことになる。しか し, 巻き張力が $100 \mathrm{~N}$ と低い場合には, ワイヤーモー ションに伴ら摩擦発熱量が $200 \mathrm{~N}$ の時よりも小さく, その結果摩擦発熱量が MQE を越える電流值 $\left(I_{q}\right)$ は $100 \mathrm{~N}$ の場合の方が高くなっているのが分かる。

このように $I_{\mathrm{q}}$ の最低点を境にして, 巻き張力の高 い側では線材の動き始める電流值, 巻き張力の低い側 ではワイヤーモーション発生後の単位時間当たりの発
熱量という異なる二つの現象が $I_{q}$ を決定する主な要 因となっている。このため， $I_{q}$ に最低点を示す巻き 張力が発生すると考えられる。

ここで例えば, Fig. 4 を参考に $100 \mathrm{~N}$ から $250 \mathrm{~N}$ 付 近の巻き張力の範囲で巻き張力と安定性について議論 を行おうとする場合について考えてみる。まず，静摩 擦係数が 0.6 の場合は, 巻き張力の増加に対し $I_{\mathrm{q}}$ は 単調に増加していく。高い巻き張力がコイルの安定性 を向上させるということは，報告されていたが12)，本 計算手法でもこのような巻き張力と $I_{q}$ との関係を明 らかにすることができたと言える。しかし一方で, 静 摩擦係数が 0.2 の場合には逆に, 巻き張力の増加に対 して $I_{\mathrm{q}}$ は単調に減少するという挙動もありうること が示されている。この計算で明らかにされたようにコ イルのクエンチ現象は, 構成材の材料特性（ここで は, 線材と巻枠との摩擦係数) や巻き張力, さらには 直接的にはワイヤーモーションが起こり始める電流 值, ワイヤーモーション発生後の発熱状態といったも のが関連して決定されるといらことを考えると、コイ ルの安定性を考える際には本計算のように包括的に様 々なパラメータと $I_{\mathrm{q}}$ との関係について議論すること が重要であると考えられる。

\section{3 クエンチ発生箇所の同定}

次にクエンチ箇所の同定を行う。クエンチが発生す る箇所は, MQE が最も小さい箇所であるのか発熱が

Vol. 32 No. 5 (1997) 


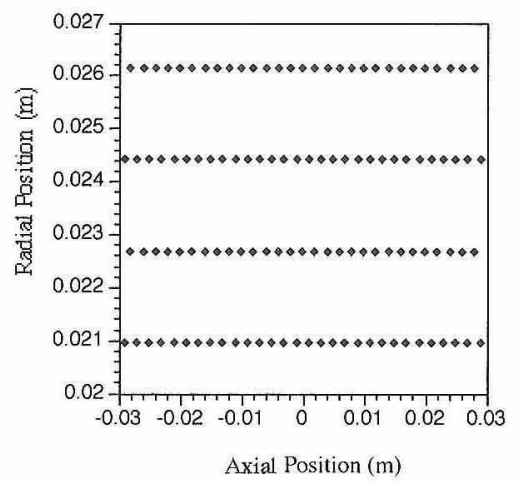

(a)

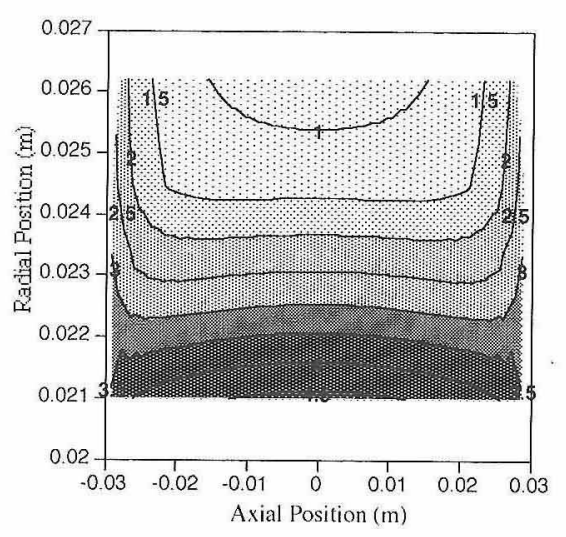

(b)

Fig. 6 (a) Wire arrangement of the calculated coil before loading. (b) Distribution of the magnetic field at a transport current of $2,355 \mathrm{~A}\left(I_{q}\right)$.

大きな筒所であるのかは，定量的な議論をしにくい問 題である。しかしながらコイルの特性の改善において はクエンチ箇所の同定は重要な意味を持つことにな る。そこでここでは, Fig. 2, Fig. 3 で示したコイル （静摩擦係数 0.2 , 動摩擦係数 0.1 , 巻き張力 $50 \mathrm{~N}$ ) の クエンチ箇所の同定を行うことにした。

Fig. 6 (a)，(b)に本解析で用いたコイルの線材の配置 及び臨界電流まで通電したときのコイルの巻線部に印 加される磁束密度分布を示した。Fig.6 (a)の縦軸は, コイル半径方向の位置を，横軸はコイル軸方向の位置 を示している。コイル内径が $40 \mathrm{~mm}$ であるので, 縦 軸は $0.02 \mathrm{~m}(20 \mathrm{~mm})$ の位置が最内層に相当する。ま たこの罒のプロットしている点は, 巻線㨁後の線材の 中心位置を示して抢り，巻乱れもなく線材は俵積み状 に整列している(縦軸と，横軸のスケールが異なって いる)。Fig.6 (b) はコイル巻線部の磁束密度分布であ るが，最大経験場 $4.5 \mathrm{~T}$ が最内層中心部で現れてい る。また，最内層の端部では，約 3.5 Tで最内層のみ を考えても1.0 程度の分布が存在する。

Fig. 7 に本コイルの摩擦発熱量の通電電流による変 化を示す。これは, Fig. 5 と同様最内層の最も発熱量 の多い線材の発熱を示している。この図から,このコ イルでは $750 \mathrm{~A}$ 程度から線材が大きく動き出すことが 理解できる。通電電流 $705 \mathrm{~A}$ の時の線材の速度分布と 発熱分布（単位は $\mathrm{J} / \mathrm{m}$ で素線 1 本あたりの発熱量で ある。素線 1 本あたり $1 \mathrm{~m}$ の体積で除せば単位体積あ たりの発熱量となる）を Fig. 8_(a)，(b)に，1,005 A の 時のそれらを Fig. 9 (a)，(b)に示した。
通電電流 $705 \mathrm{~A}$ では，線材の速度はほとんど $0 \mathrm{~m} / \mathrm{s}$ で，ワイヤーモーションはほとんど生じていない。そ のため摩擦発熱もほとんど生じておらず，最内層の巻 枠と接している簡所の発熱量泜いことが理解でき る。一方 1,005 A の時は Fig.9 (a)に示すように, 線 材部は全体として軸方向に圧縮されるので, コイルの つば部で大きな速度を持つ分布を示す (Fig. 8 (a) と スケールは 1 桁異なる)。このような線材の動きに伴 い，巻線部の最内層と巻枠胴部のつば部付近で大きな 摩擦発熱が生じ，発熱分布は，Fig.9 (b) に示すような 分布となる (Fig. 8 (b) とスケールは1﨓異なる)。こ れは理想的に巻線しても，端部の方が中心部と比較し て動きやすく大きな発熱を生じることを意味してい る。なお, Fig. 8 (a), Fig.9 (a) で線材の速度分布が左

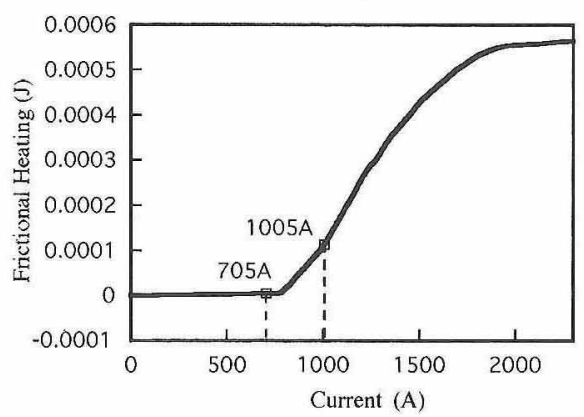

Fig. 7 Change in frictional heating with excitation. Static frictional coefficient (SFC), dynamic frictional coefficient (DFC) and winding tension are $0.2,0.1$ and $50 \mathrm{~N}$, respectively. 


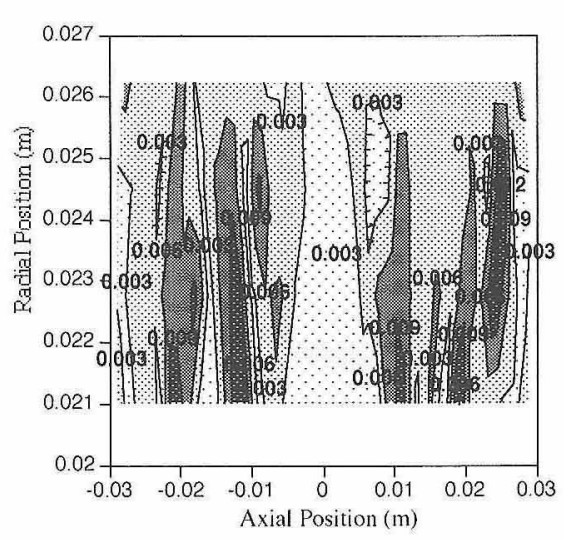

(a)

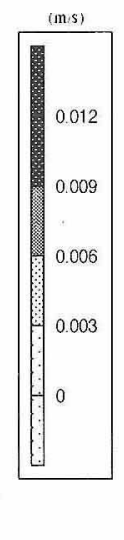

Fig. 8 (a) Distribution of wire velocity; (b) Frictional heating at a transport current of $705 \mathrm{~A}$.

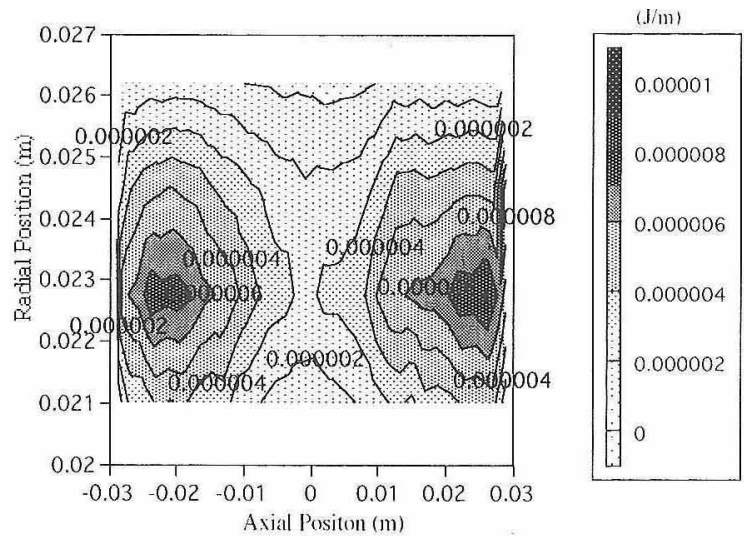

(b)
右対称から若干ずれているが，これは計算の丸め誤差 が影響したものと考えられる。

これらのデータを基に詳細な検討を行うと，この場 合のクエンチ箇所は, 最内層の左から 8 番目の位置, Fig. 6 では $(-0.015,0.021)$ の線材でクエンチが発 生したことが明らかになった。また，巻き張力 $450 \mathrm{~N}$, 静摩擦係数 0.2 , 動摩擦你数 0.1 の時には, 最内層左 から 2 番目の線材からクエンチが始まる。このことか ら，クエンチの生じる箇所は，MQE が最小の箇所で む摩擦発熱が最大の箇所でもなく，その両者の複雑な 兼ね合いとして決定されるということが明らかになっ た。つまり，クエンチの発生する籄所は，コイル内の 磁場の分布状況やワイヤーモーションの発生の有無と その発熱状況，つまり，コイルの形状や，コイルの構

成によりその発生箇所が変化する可能性があると言え る。

\section{4 コイル内応力分布}

Fig. 10 (a)，(b)にコイル励磁前及びクエンチ後のコ イル内の応力分布を示した（解析対象は Fig. 2，3で 示した巻き張力 $50 \mathrm{~N}$, 静摩擦係数 0.2 , 動摩擦係数 0.1 のコイルである)。単位は $(\mathrm{N} / \mathrm{m})$ で素線 1 本 $1 \mathrm{~m}$ あたりに䡃く力 (スカラー量)で表している。䩦密に は応力ではなく力分布であるが以下「応力」の言葉を 使用する。なお，この力を線材の長手断面 ( $2 \mathrm{~mm} \times$ $1,000 \mathrm{~mm}$ ) で除せば線材中心面上での応力となる。励 磁前には応力分布は，コイル内層ほど応力が高くなっ て㧍り, 最も高以巻線胴部付近では $14,000 \mathrm{~N} / \mathrm{m}$ 程度 となっている。これは，上層の線材の張力によるフー

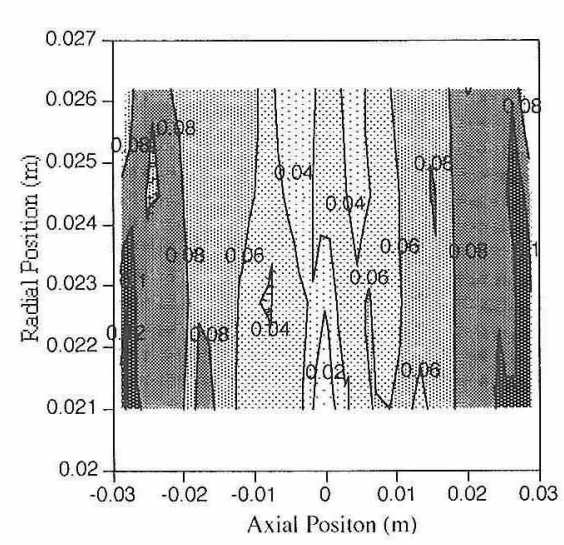

(a)
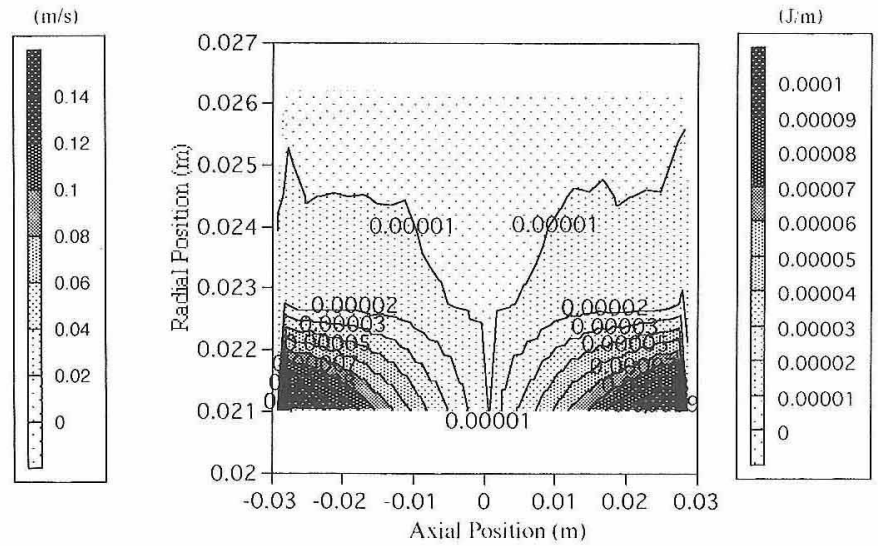

(b)

Fig. 9 (a) Distribution of wire velocity; (b) Frictional heating at a transport current of 1,005 A.

Vol. 32 No. 5 (1997) 


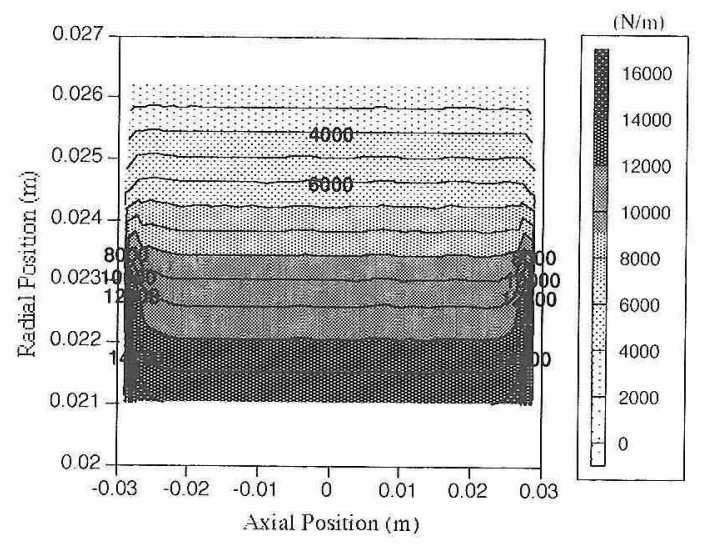

(a)

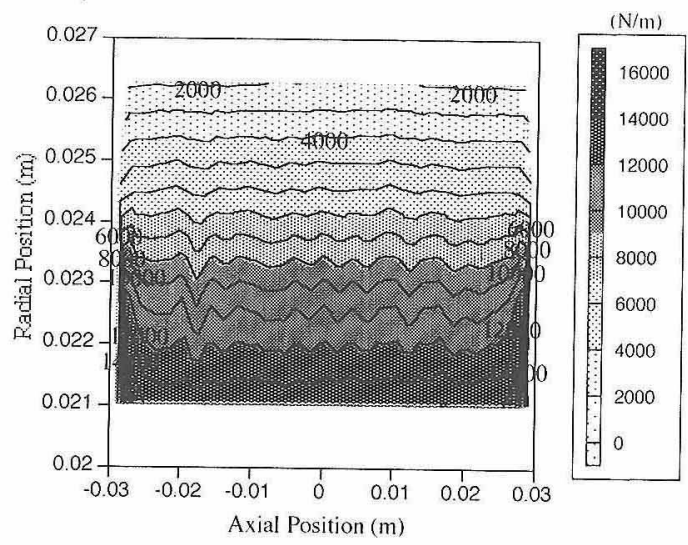

(b)

Fig. 10 Stress distribution. (a) Before energizing; (b) After quench.

プ力により下層が圧縮されているためと考えられる。 このためコイル上層に行くほど応力は下がっている。 また，端部では巻枠つば部に押さえつけられるため複 雑な応力分布となっている。(b) はクエンチ後の応力分 布であるが，コイル内の応力分布は，内層ほど内部応 力が高くなり，最も高くなる最内層部では $14,000 \mathrm{~N} /$ $\mathrm{m}$ となる等, 大まかな点では励磁前の応力分布と一致 しているが，クエンチ後の図では，応力分布の境界 や，つば部付近で，応力の分布が不規則になっている ことが分かる。なおここで導かれたコイル最内層の 線材に衔く応力の方が，Fig. 2 における巻枠反力と比 較して大きくなっている。これは，巻枠反力は, フー プカのため素線に働く力より小さくなることを意味し ている(多重円筒モデルを考えると理解できる)。Fig. 11 に励磁前とクエンチ後の第 2 層の線材の中心 位 置 を示した。本図より，励磁後線材は元の位置に戻って いないことがわかり，これがクエンチ後応力分布が不 規則になる理由と考えられる。このような通電前後の 線材位置の変化, 応力状態の変化は, 実際のコイルに 招いても発生すると考えられ，続く励磁において異な る発熱挙動が起こると考えられる。そして，そのため に異なる $I_{\mathrm{q}}$ となることが予想され，トレーニング挙 動や電流劣化現象を引き起こすと考えられる。

さて，本研究により開発された計算手法は，通電中 の時々刻々の応力分布を追跡することもできる。即 ち, 励磁前, 励磁中及びクエンチ後の応力分布が変化 していく過程を検討することができる。まず，励磁に 伴う応力分布の変化を Fig. 12 (a) (d) に示した。この コイルの巻線部が巻枠っば部から離れるのは, $930 \mathrm{~A}$,
胴部から浮き上がるのは $2,001 \mathrm{~A}$ の時である（各図で 応力のスケールが異なっていることに注意)。またこれ らの図では, 巻線部の浮き上がりが起こっても線材に 㗢く力は $0 \mathrm{~N}$ とはならない。これは前述したよらに, 本図では，線材に働く力を示しているので，巻枠から 浮き上がっても，電磁力やフープカ, 素線同士の力が 働いているからである。コイル内の応力分布は通電電 流の増加に伴い Fig. 12 (a) 〜 (d) に示すように徐々に変 化していき，最終的には巻線部の中心付近が最大とな るような分布を示すようになる。

Fig. 13 にコイルクエンチ前後の巻枠胴部の反力の 時間変化を示した。 8,667 ステップ $(2,001 \mathrm{~A})$ で胴部 からの反力が $0 \mathrm{~N}$ となり巻線部が巻枠から浮き上がっ ている。また，8,797 ステップ (2,391 A) でクエンチ し, その後に巻線部が巻体と突衝し, 高い反力を示し ながら徐々に隇衰していき，9,200 ステップでは巻枠

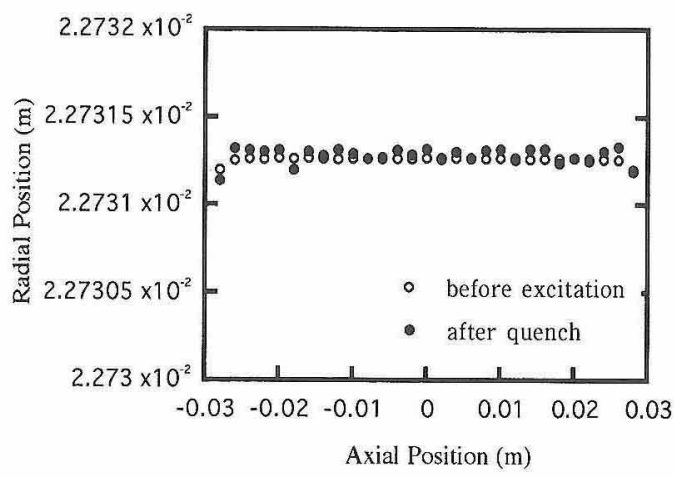

Fig.11 Change of wire position at second layer before excitation and after quench. 


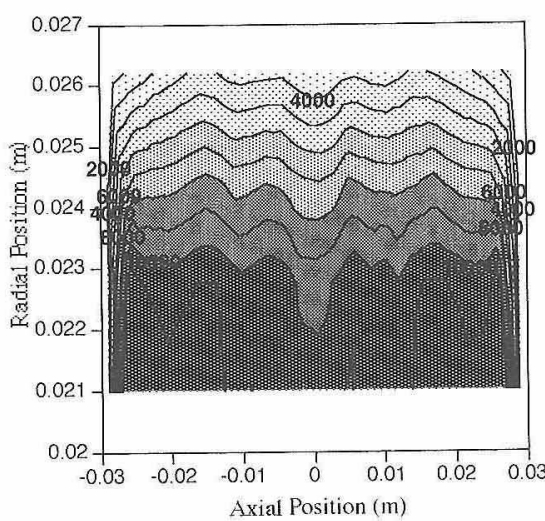

(a)

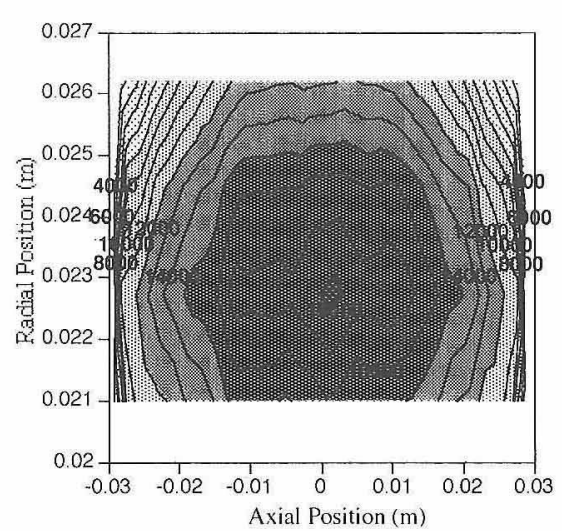

(c)
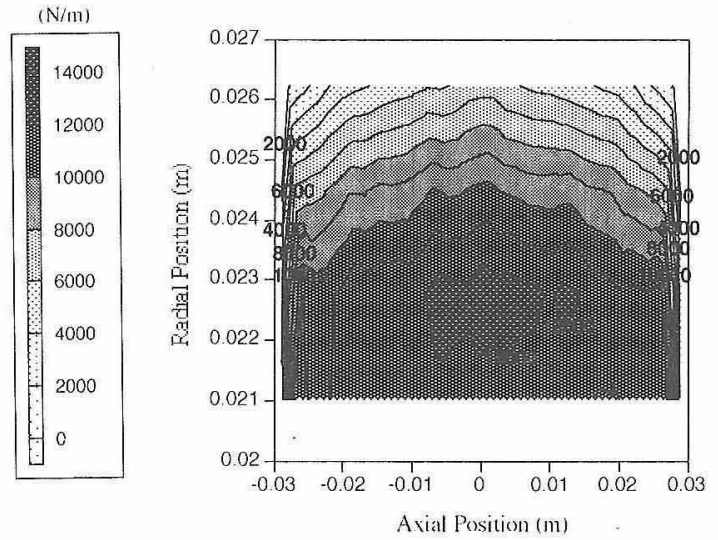

(b)
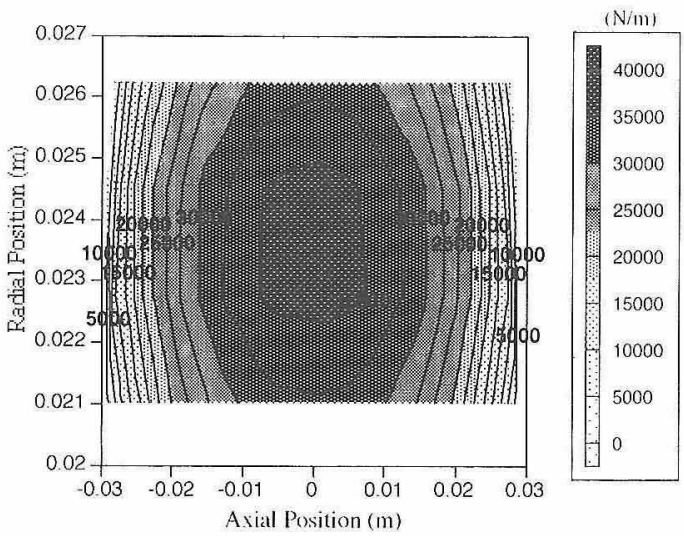

(d)

Fig. 12 Stress distribution at transport currents of (a) $945 \mathrm{~A}$, (b) 1,065 A, (c) 1, $305 \mathrm{~A}$ and (d) 1,905 A.

反力は落らつき，励磁前とほぼ同じレベルに復帰して いる。なお，この復帰後には巻乱れが生じているのは 前述したとおりである。この過程での巻線部の応力 分布を追跡する。クエンチ前後の応力分布を Fig. 14 (a)〜 (c) に示した。

Fig. 14 (a)にクエンチ直前，(b)に電流を遮断し (Fig. 3 のようにクエンチと同時に電流を0A まで下 ゲたという意味) $3.5 \mu \mathrm{s}$ 後, (c)に6 $\mu$ 後のコイル内の 応力分布を示している。これらは Fig.13 中に示され ている (i)，(ii)，(iii) と時間的に対応している。Fig. 14 (a) でコイルの中心に集中している応力は $(55,000 \mathrm{~N} / \mathrm{m}$ (27.5 MPa))，電流の遮断とともに解放されはじめ， (b) では約 $45,000 \mathrm{~N} / \mathrm{m}$ まで減少している。そして (c) では，巻枠胴部でやや㐫力の高い部分が分布するよう になるが，これは最内層の線材が，巻枠胴部に衝突す
るためと考えられる。これは, Fig. 13 に示した (ii) で, 巻枠反力が上昇していることからもわかる。そしてこ

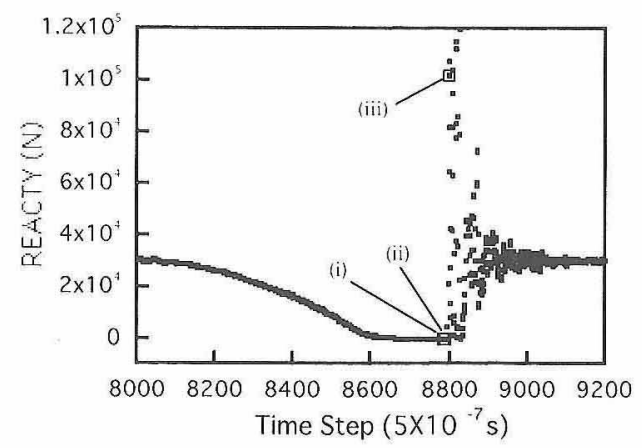

Fig. 13 Change of reaction force from bobbin barrel before and after quench at a winding tension of $50 \mathrm{~N}$. 


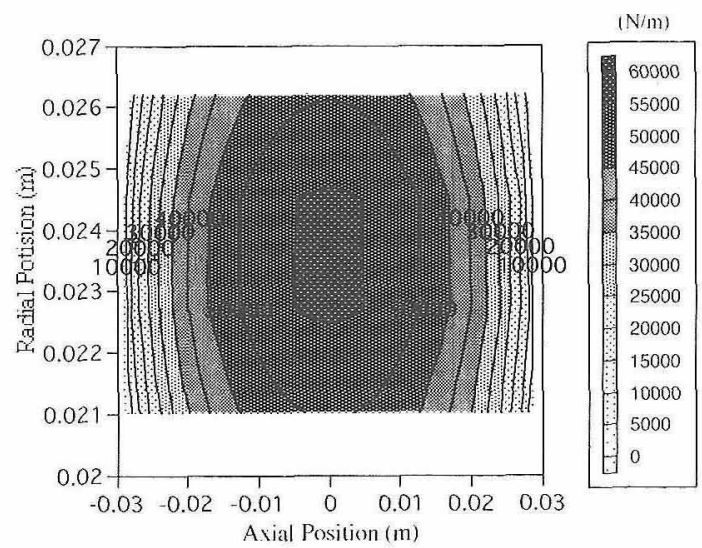

(a)

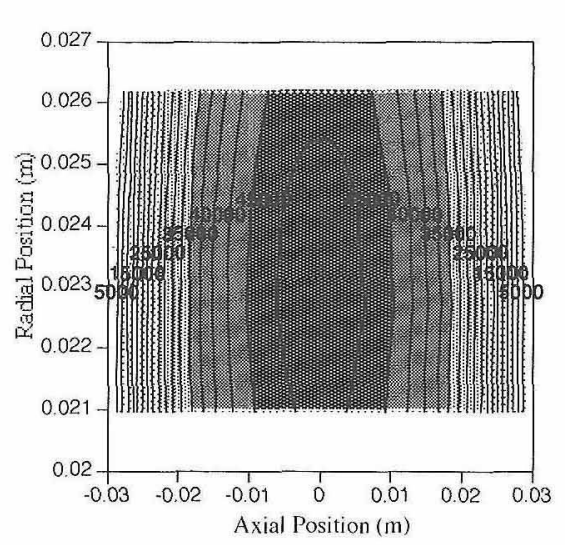

(b)

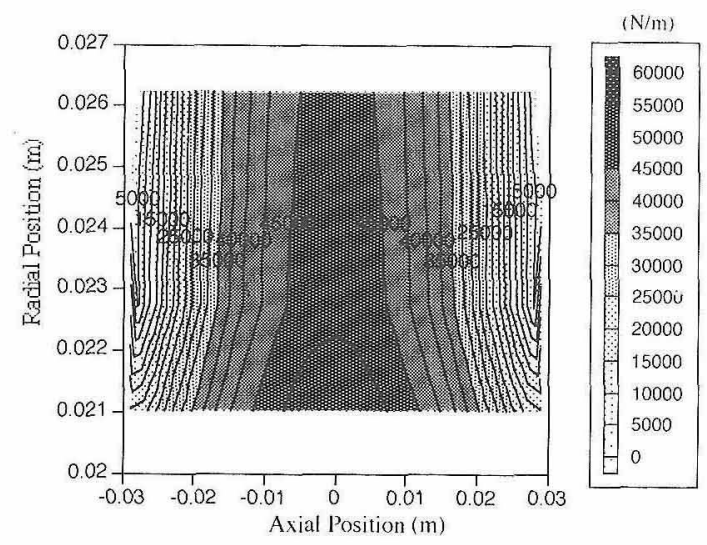

(c)

Fig. 14 Stress distribution. (a) At transport current of 2, 355 A $\left(I_{q}\right)$; (b) At $3.5 \mu \mathrm{s}$ after quench; (c) At $6.0 \mu \mathrm{s}$ after quench.
のように巻枠との衝突を繰り返すことにより, Fig. 13 に示すような減衰振動を示すようになると考えられ る。一連の Fig. 12 と Fig. 14 を比較して，コイル内応 力分布の変化の栐子は励磁中と電流遮断後では大きく 異なることが分かる。特に，電流遮断後の忠力分布は 線材が平衡位置に至る前に変化し，これが原因となっ て Fig.14 に示すような巻き乱れを生ずると考えられ る。逆に, クエンチ後適切な電流遮断速度で電流遮断 を行えば，巻乱れの生じない状態を実現できる可能性 があることが推定される。

\section{4. 結論}

本研究で開発されたコイル内の線材の運動方程式を 時間発展で解いていく方法により，コイルの安定性 と，摩擦係数，巻き張力の関係を定量的に明らかにす ることができた。特に，(1) $I_{q}$ は巻き張力により変化 し， $I_{q}$ が最小となる巻き張力が存在する。(2) $I_{q}$ が最 小となる巻き張力の値は, 摩擦係数で異なることが明 らかになった。さらに，クエンチ箘所の同定を行った ところ, (3) クエンチの発生する場所は, MQE の最小 の箇所でも発熱量の最大の箇所でもない。(4) クエンチ 発生簤所は巻き張力や摩擦係数で変化することが明ら がなった。

また, クエンチ後のコイル内の忘力分布も明らかに することができ（5)線材がコイル巻枠を打撃しなが ら, 元の位置に戻ろうとするため, 摩擦力が作用し, 元の配置まで復帰できないことがある。(6)この線材の 配置の乱れが電流劣化現象を引き起こす可能性がある ことも明らかになった。

以上の上うに，本研究で開発された解析法は励磁前 から励磁後まで時々刻々のコイル内の線材の動き, 速 度分布，発熱分布，応力分布等を計算することができ るため，安定なコイル製作の具体的指針を与え得る解 析方法となることが期待できる。当報告では密巻きコ イルを対象に解析を行ったが，現在 $\mathrm{CIC}$ 導体への応 用を検討している。

\section{参考文献}

1) Y. Iwasa: IEEE Trans. Magn. 28 (1992) 113

2) O. Tsukamoto and Y. Iwasa: IEEE Trans. Magn. 19 (1983) 443

3) R. S. Kensley, H. Maeda and Y. Iwasa: IEEE Trans. Magn. 17 (1981) 1068

4) H. Maeda, O. Tsukamoto and Y. Iwasa: Cryogenics 22 (1982) 287 
5) R. S. Kensley, H. Maeda and Y. Iwasa: Cryogenics 21 (1981) 479

6) O. Tsukamoto, H. Maeda and Y. Iwasa: Appl. Phys. Lett. 39 (1981) 172

7) R. S. Kensley and Y. Iwasa: Cryogenics 20 (1980) 25

8) S. Nishijima, T. Kushida and T. Okada: Simulation of wire movement in a superconducting coil, presented ASC'96 Pittsburgh LBA-8 (1996)

9) T. Kushida, S. Nishijima and T. Okada:
Calculation of wire motion in a superconducting magnet, presented ASC '96 Pittsburgh LBA-9 (1996)

10) 川田雄一ら：材料工学ハンドブック, 朝 倉 書 店, 東京 (1966) 240

11) M. Urata and H. Maeda: IEEE Trans. Magn. 25 (1983) 1528

12) K. Ikizawa, N. Takasu, Y. Murayama, K. Keo, S. Nishijima, K. Katagiri and T. Okada : IEEE Trans. Magn. 27 (1991) 2128 